\title{
PENGARUH PANDEMIK COVID-19 TERHADAP GERAKAN TRANSPORTASI DI JABODETABEK
}

\author{
THE INFLUENCE OF PANDEMIC COVID-19 ON \\ TRANSPORTATION MOVEMENT IN JABODETABEK
}

Sylvira Ananda Azwar ${ }^{\mathbf{a}, 1^{*}}$, Yusuf Abdurrohman ${ }^{\mathbf{b}, 2,}$

aProdi D III Transportasi, Fakultas Teknik - Universitas Negeri Jakarta

bProdi D III Transportasi, Fakultas Teknik - Universitas Negeri Jakarta

1*sylvira_a@unj.ac.id, ${ }^{2}$ abdrhmnyusuf18@gmail.com,

*corresponding e-mail: $\underline{\text { admind3transportasi@unj.ac.id }}$

\begin{abstract}
The research method used is by distributing questionnaires to respondents who are Jabodetabek people. The analyzes carried out were analysis of travel destinations, analysis of origin and destination areas, and analysis of modal choices during the Covid-19 pandemic to large-scale social restrictions (PSBB). The results of distributing questionnaires with 150 respondents stated that there was a decrease in movement in Jabodetabek by a percentage of $38 \%$. The decrease occurred in $36 \%$ of recreational trips, $34 \%$ of education, $28 \%$ of work and $23 \%$ of social activities. The rate of increase in private vehicles is $25 \%$. From these results it can be stated that the Covid-19 pandemic has an influence on the movement of people and transportation in Jabodetabek. Some suggestions in this regard are increasing travel supervision and tightening health protocols in each mode, as well as improving services on public transportation when trips have returned to normal by adding schedules and fleets to public transportation to reduce congestion so as to maintain health protocols in public transport.
\end{abstract}

Keywords: Influence, Movement, Transportation, Covid-19.

\begin{abstract}
ABSTRAK
Metode penelitian yang digunakan yaitu dengan menyebarkan kuesioner kepada responden yang merupakan masyarakat Jabodetabek. Analisis yang dilakukan adalah analisis destinasi perjalanan, analisis daerah asal dan tujuan, serta analisis pilihan moda selama pandemi Covid19 hingga restriksi sosial skala besar (PSBB). Hasil penyebaran kuisioner terhadap 150 responden menyatakan terjadi penurunan pergerakan di Jabodetabek dengan persentase sebesar $38 \%$. Penurunan terjadi pada $36 \%$ perjalanan rekreasi, $34 \%$ pendidikan, $28 \%$ pekerjaan dan $23 \%$ kegiatan sosial. Tingkat kenaikan kendaraan pribadi adalah $25 \%$. Dari hasil tersebut dapat dikatakan bahwa pandemi Covid-19 berpengaruh terhadap pergerakan manusia dan transportasi di Jabodetabek. Beberapa saran dalam hal ini adalah meningkatkan pengawasan perjalanan dan memperketat protokol kesehatan di setiap moda, serta meningkatkan pelayanan pada angkutan umum ketika perjalanan sudah kembali normal dengan menambah jadwal dan armada pada angkutan umum untuk mengurangi kemacetan guna menjaga protokol kesehatan di masyarakat. mengangkut.
\end{abstract}

Kata kunci : Pengaruh, Pergerakan, Transportasi, Covid-19. 


\section{A. Pendahuluan}

Tahun 2020 telah menjadi tahun yang sangat sulit bagi orang-orang di seluruh dunia. Pada tahun tersebut terjadi wabah penyakit yang disebabkan oleh virus Covid-19. Virus ini menghambat semua aktivitas di dunia. Covid-19 merupakan virus penyakit menular yang disebabkan oleh virus corona SARS-CoV-2 yang pertama kali muncul pada Desember 2019 di kota Wuhan. Virus ini telah menginfeksi hampir seluruh negara di dunia termasuk Indonesia, sehingga Badan Kesehatan Dunia (WHO) menyatakannya sebagai pandemi global. Di Indonesia kasus pertama terdeteksi pada 2 Maret 2020. Salah satu sektor yang terkena pandemi di Indonesia yaitu transportasi. Transportasi adalah suatu proses perpindahan dari suatu tempat asal ke suatu tujuan dengan tujuan tertentu. Transportasi merupakan faktor yang sangat penting dalam kehidupan yang memiliki peran untuk menunjang aktivitas manusia sehari-hari. Jabodetabek merupakan daerah dengan jumlah penduduk yang besar di Indonesia, sehingga memiliki pergerakan transportasi yang sangat tinggi. Akibat tingginya aktivitas dan pertemuan, kawasan ini menjadi kawasan terluas yang terdampak virus Covid-19 di Indonesia, sehingga dapat mencegah penyebaran pemerintah yang menerapkan kebijakan jarak fisik hingga pembentukan Pembatasan Sosial Skala Besar (PSBB). untuk wilayah Jabodetabek.

\section{B. Metode Penelitian}

Dalam penelitian ini pengumpulan data diperoleh dengan observasi langsung (survei), wawancara (interview), dan penyebaran kuesioner kepada responden. Jumlah sampel yang diambil dalam penelitian ini sebanyak 150 responden. Seluruh pengambilan sampel digunakan sebagai data primer dalam penelitian ini, kemudian data sekunder diperoleh dengan mempelajari literatur yang berkaitan dengan penelitian serta dokumen pendukung yang diperoleh langsung dari perusahaan. Analisis dilakukan dengan menghitung persentase maksud dan tujuan perjalanan, serta pilihan moda responden sebelum Covid-19 hingga pembatasan sosial skala besar (PSBB).

\section{Hasil dan Pembahasan}

Jabodetabek adalah kawasan metropolitan Jakarta dan sekitarnya. Kawasan ini mencakup wilayah administrasi DKI Jakarta, Kota Bogor, Kabupaten Bogor, Kota Depok, Kota Tangerang, Kota Tangerang Selatan, Kabupaten Tangerang, Kota Bekasi, dan Kabupaten Bekasi . Menurut Badan Pusat Statistik (BPS) pada tahun 2019 jumlah penduduk Jabodetabek 
yang berusia 5 tahun ke atas sebanyak 29.313.171 dan $11,1 \%$ dari jumlah tersebut melakukan perjalanan antar kabupaten/kota atau berstatus sebagai komuter.

1. Tujuan perjalanan

Analisis ini menghitung persentase tujuan perjalanan responden sebelum Covid-19 ke PSBB. Berdasarkan hasil analisis tersebut dapat diketahui bahwa terdapat perubahan perjalanan akibat adanya Covid-19. Analisis jumlah perjalanan dilakukan dengan membandingkan tujuan perjalanan sebelum COVID-19 dengan PSBB pada Mei 2020.Berikut data niat perjalanan responden.

Persentase Responden yang Melakukan Perjalanan Selama Pandemi Covid-19

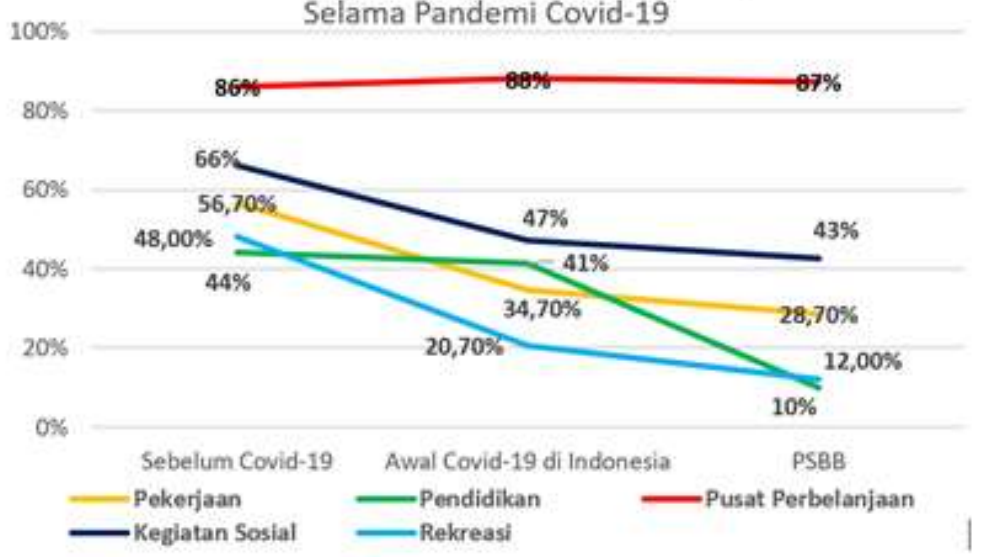

Berdasarkan data di atas terlihat bahwa persentase yang perjalanan dengan maksud bekerja mengalami penurunan total dari sebelum Covid-19 ke PSBB sebesar 28\%. Persentase bepergian dengan tujuan pendidikan telah menurun dari sebelum pandemi Covid-
19 ke PSBB sebesar 34\%. Sehingga dapat disimpulkan bahwa pandemi Covid-19 dan PSBB sangat mempengaruhi perjalanan untuk tujuan pendidikan. Persentase yang bepergian dengan tujuan pusat perbelanjaan relatif tidak terpengaruh oleh masuknya Covid-19. Hanya terjadi penurunan sebesar $1 \%$ selama penerapan Pembatasan Sosial Skala Besar (PSBB). Berdasarkan data di atas menunjukkan bahwa keberadaan Covid-19 sangat mempengaruhi perjalanan responden untuk berekreasi. Persentase penurunan total perjalanan untuk tujuan rekreasi adalah $36 \%$.

\section{Analisis Destinasi Perjalanan}

Analisis ini dilakukan untuk mendapatkan peta perjalanan dari responden yang melakukan perpindahan antar kabupaten / kota di wilayah Jabodetabek. Analisis dilakukan dengan menanyakan asal dan tujuan responden yang merupakan bagian dari rutinitas mereka dalam berwisata. Dari hasil penyebaran kuisioner yang diperoleh dari total 150 responden, diketahui $6 \%$ diantaranya melakukan perpindahan antar kabupaten / kota di wilayah Jabodetabek sebelum terjadinya 
pandemi Covid-19 berdasarkan tabel berikut.

Tabel Jumlah Responden Yang Bepergian Antar Kabupaten / Kota di Jabodetabek Melakukan Pergerakan Antar Jabodetabek.

\begin{tabular}{|l|l|l|l|}
\hline $\begin{array}{l}\text { Melakukan pergerakan } \\
\text { antar jabodetabek }\end{array}$ & $\begin{array}{l}\text { Sebelum } \\
\text { Covid-19 }\end{array}$ & $\begin{array}{l}\text { Awal covid-19 di } \\
\text { indonesia }\end{array}$ & PSBB \\
\hline Ya & 141 & 114 & 84 \\
\hline Tidak & 9 & 36 & 66 \\
\hline Jumlah & 150 & 150 & 150 \\
\hline
\end{tabular}

$\%$ Sebelum Covid-19

$=\sum$ bepergian $\mathrm{x} 100$

Jumlah responden

$=\underline{141 \times 100 \%}$

150

$=94 \%$

\% Covid-19 Awal di Indonesia

$=\sum$ bepergian $\mathrm{x} 100$

Jumlah responden

$=\underline{114 \times 100 \%}$

150

$=76 \%$

$\%$ Saat PSBB

$=\sum$ perjalanan $\mathrm{x} 100$

Jumlah responden

$=\underline{84 \times 100} \%$

150

$=56 \%$
Persentase Pergerakan Responden Antar Jabodetabek

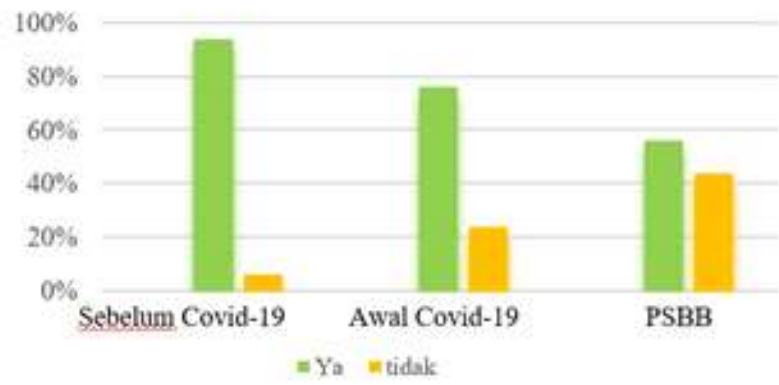

Diketahui, jumlah perjalanan responden komuter sebelum pandemi Covid-19 di Indonesia ke PSBB mengalami penurunan sebesar 38\%. Penurunan jumlah perjalanan juga didukung dengan rekomendasi bekerja dari rumah (WFH), belajar dan beribadah di rumah. Berikut adalah grafik jumlah pergerakan / perjalanan responden.

Jumlah perjalanan yang dilakukan oleh responden sudah jelas yang ditunjukkan dengan jumlah jalur perjalanan yang lebih sedikit. Selain berwisata di Jabodetabek, responden juga berwisata ke luar kota Jabodetabek. Persentase responden yang berwisata ke luar Jabodetabek diketahui mengalami penurunan sebesar 21,33\%. Perjalanan tersebut didominasi oleh tujuan sosial seperti bertemu dengan kerabat, daerah yang dikunjungi responden masih berada di Pulau Jawa. 


\begin{tabular}{|l|l|l|l|}
\hline $\begin{array}{l}\text { Perjalanan Ke } \\
\text { Luar Jabodetabek }\end{array}$ & $\begin{array}{l}\text { Sebelum } \\
\text { Covid-19 }\end{array}$ & $\begin{array}{l}\text { Awal Covid-19 } \\
\text { Di Indonesia }\end{array}$ & PSBB \\
\hline Ya & 66 & 34 & 34 \\
\hline Tidak & 84 & 116 & 116 \\
\hline Jumlah & 150 & 150 & 150 \\
\hline
\end{tabular}

Perhitungan perjalanan ke kuar

Jabodetabek

1. Sebelum Covid-19

Persentase

$=\sum$ melakukan perjalanan $\mathrm{x} 100$

Jumlah responden

$=66 \times 100 \%$

150

$=44 \%$

2. Awal Covid-19 di Indonesia

$=\sum$ melakukan perjalanan

Persentase

$=\sum$ melakukan perjalanan $\mathrm{x} 100$

Jumlah responden

$=34 \times 100 \%$

150

$=22,67 \%$

\section{Saat PSBB}

Persentase

$=\sum$ melakukan perjalanan $\mathrm{x} 100$

$=34 \times 100 \%$
$=22,67 \%$

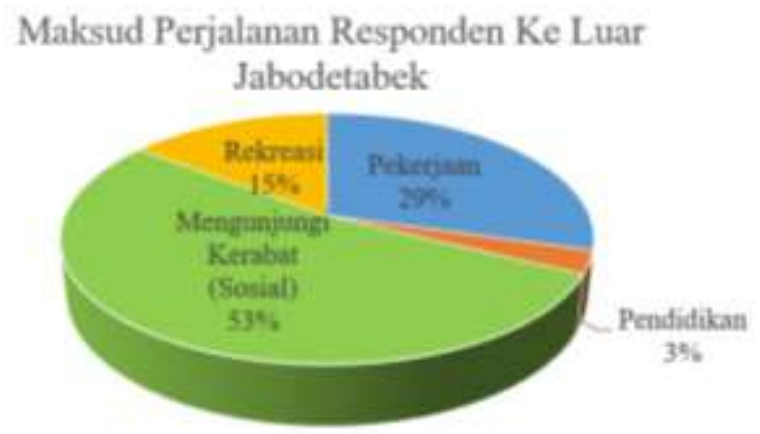

Gambar 1. Persentase Maksud Perjalanan Responden Ke Luar Jabodetabek

Perjalanan Responden ke Luar Jabodetabek Selama Pandemi Covid -19

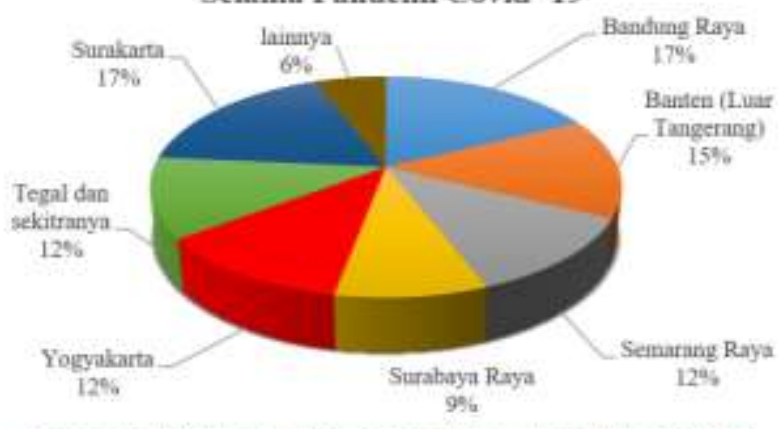

Persentase Perjalanan Responden Tujuan Luar Jabodetabek

Gambar 2. Persentase Perjalan Responden

Dari grafik tersebut terlihat bahwa daerah yang paling banyak dikunjungi responden selama periode pandemi hingga PSBB adalah Surakarta dan Bandung dengan persentase sebesar 17\%. Namun secara keseluruhan terlihat bahwa kota-kota yang banyak dikunjungi responden berada di Provinsi Jawa Tengah yaitu Surakarta 17\%, Semarang 12\%, dan Tegal $12 \%$. Sehingga secara keseluruhan persentase responden yang berkunjung ke Jawa 
Tengah menjadi 41\%. Hal ini serupa dengan jumlah tujuan penumpang ke Pulau Jawa di Terminal Terpadu Pulo Gebang yang diambil dari data boading pass terminal pada Maret 2020.

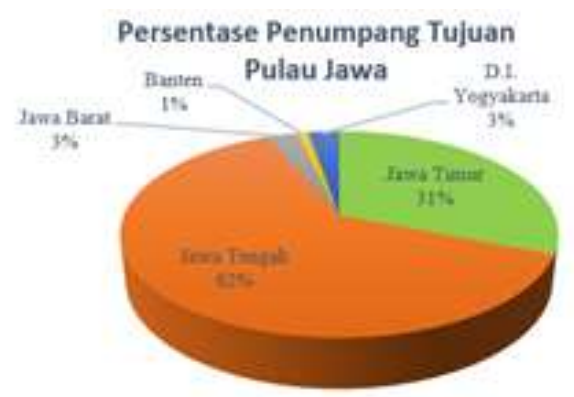

Persentase Pentumpang Tujuan Pulau Jawa di Terminal Terpadu Pulo Gersymoda pribadi x 100

Sumber: Terminal Terpadu Pulo Gebang

3. Analisis Pemilihan Moda

Responden Selama Pandem Covid2019.

Analisis ini dilakukan untuk mengetahui perubahan yang terjadi pada pilihan moda yang digunakan responden selama pandemi Covid-19. Analisis pemilihan moda dilakukan dengan membandingkan mode yang digunakan sebelum Covid-19 dengan PSBB pada Mei 2020.

Tabel 3. 1 Jumlah Jenis Kendaraan Yang Digunakan Responden

\begin{tabular}{|c|c|c|c|}
\hline $\begin{array}{ll}\text { Kendaraan } & \text { Yang } \\
\text { Digunakan } & \\
\end{array}$ & $\begin{array}{l}\text { Sebelum } \\
\text { Covid-19 }\end{array}$ & $\begin{array}{l}\text { Awal Covid-19 } \\
\text { Di Indonesia }\end{array}$ & Saat PSBB \\
\hline Pribadi & 99 & 124 & 136 \\
\hline Umum & 51 & 26 & 14 \\
\hline Jumlah & 150 & 150 & 150 \\
\hline
\end{tabular}

Perhitungan Pemilihan moda

1. Sebelum Covid-19

$\%$ Moda Pribadi

$=\sum$ moda pribadi $\mathrm{x} 100$
Jumlah responden

$=\underline{124 \times 100 \%}$

150

$=82,67 \%$

\% Moda Umum

$=\sum$ moda umum $\times 100$

Jumlah responden

$=\underline{26 \times 100 \%}$

150

$=17,33 \%$

3. Saat PSBB

\% Moda Pribadi

$=\sum \underline{\text { moda umum } \mathrm{x} 100}$

Jumlah responden

$=\underline{136 \times 100 \%}$

150

$=90,67 \%$

\% Moda Umum

$=\sum$ moda umum $\times 100$ 
Jumlah responden

$=1 \underline{4 \times 100 \%}$

150

$=9,33 \%$

\section{Persentase Pemilihan Moda Responden}

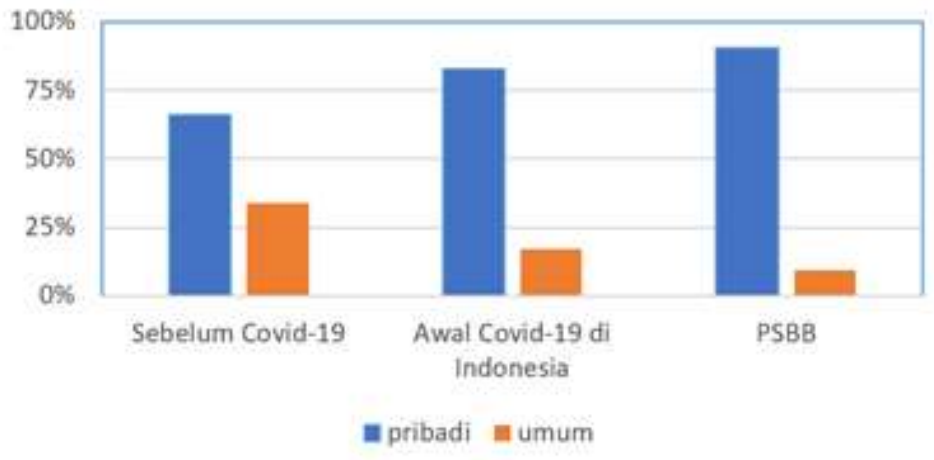

Persentase Pemilihan Moda Selama Covid-19

Berdasarkan grafik di atas, bahwa responden lebih banyak menggunakan kendaraan pribadi daripada angkutan umum. Alasan utama responden cenderung memilih kendaraan pribadi masih didominasi oleh kenyamanan dan waktu tempuh yang lebih cepat, karena tidak harus transit dan berganti moda. Selain itu, mereka menghindari penyebaran virus saat berada di angkutan umum yang ramai.

Dari hasil pengolahan data tersebut, responden yang menggunakan kendaraan pribadi, kendaraan pribadi mengalami peningkatan sebesar $24,67 \%$ dari sebelum pandemi Covid-19 sampai PSBB. Di sisi lain, pengguna angkutan umum mengalami penurunan sebesar $25 \%$. Hal tersebut menunjukkan bahwa keberadaan Covid-19 sangat memengaruhi pilihan moda perjalanan. Perubahan jumlah pengguna angkutan umum dan kendaraan pribadi juga dipengaruhi oleh adanya kebijakan dari pemerintah yang membatasi pelayanan angkutan umum yang meliputi jam operasional, pengurangan kapasitas dan fasilitas lainnya.

\begin{tabular}{|l|l|l|l|l|l|l|}
\hline $\begin{array}{l}\text { Moda Yang } \\
\text { Digunakan }\end{array}$ & $\begin{array}{l}\text { Sebelum } \\
\text { Covid-19 }\end{array}$ & $\mathbf{( \% )}$ & $\begin{array}{l}\text { Awal Covid-19 } \\
\text { Di Indonesia }\end{array}$ & $\mathbf{( \% )}$ & PSBB & $\mathbf{( \% )}$ \\
\hline Sepeda & 0 & 0 & 6 & 4 & 7 & 4.67 \\
\hline Sepeda motor & 77 & 51.33 & 80 & 53.33 & 92 & 61.33 \\
\hline Mobil & 22 & 14.67 & 38 & 25.33 & 37 & 24.67 \\
\hline Tranjakarta & 24 & 16 & 12 & 8 & 3 & 2 \\
\hline KRL & 13 & 8.67 & 8 & 5.33 & 9 & 6 \\
\hline Angkot & 3 & 2 & 2 & 1.33 & 2 & 1.33 \\
\hline Angkutan Online & 8 & 5.33 & 2 & 1.33 & 0 & 0 \\
\hline Transjabodetabek & 3 & 2 & 2 & 1.33 & 0 & 0 \\
\hline Jumlah & 150 & 100 & 150 & 100 & 150 & 100 \\
\hline
\end{tabular}

Dari tabel di atas terlihat bahwa pemilihan moda sepeda motor mendominasi pada setiap periodenya. Pada kendaraan pribadi, peningkatan tertinggi terjadi pada sepeda motor dan mobil yaitu $10 \%$ dari sebelum pandemi Covid-19 hingga PSBB. Sedangkan sepeda mengalami peningkatan sebesar 5\% saat pembatasan sosial skala besar. Untuk melihat secara jelas peningkatan persentase pengguna kendaraan pribadi, maka grafiknya disajikan sebagai berikut. 


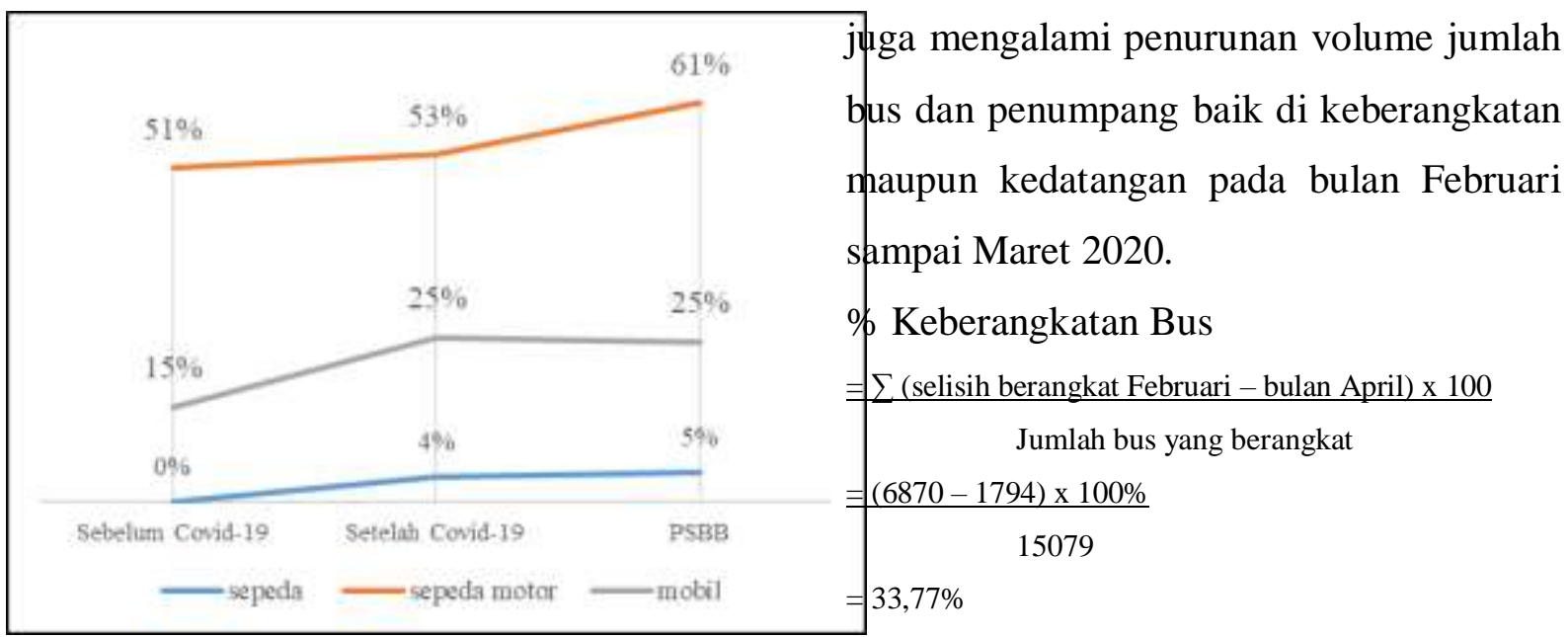

Pada moda angkutan umum pada tabel diatas terlihat bahwa Transjakarta mengalami penurunan yang sangat besar dibandingkan moda lainnya yaitu sebesar $14 \%$ sampai dengan pembatasan sosial skala besar. Sedangkan angkutan online dan KRL mengalami penurunan sebesar $4 \%$ dan 3\%. Berikut grafiknya.

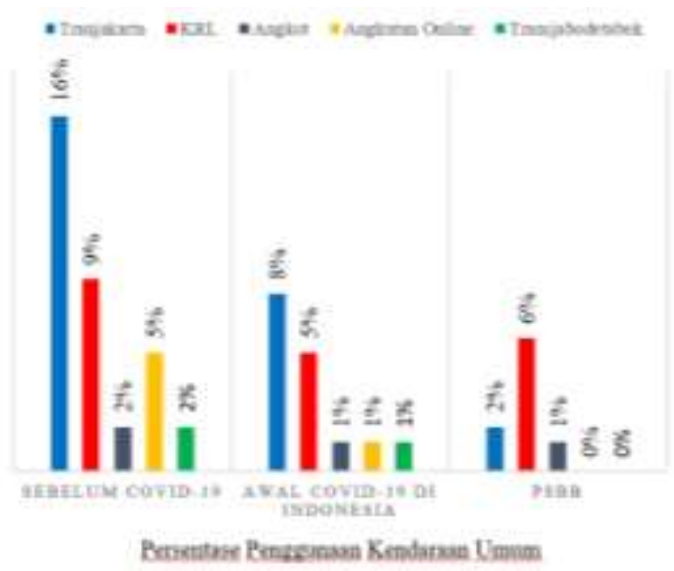

Tabel Volume Jumlah Bus dan Penumpang di Terminal Terpadu Pulo Gebang 2020

\begin{tabular}{|l|l|l|l|l|l|l|}
\hline \multirow{2}{*}{ Bulan } & \multicolumn{4}{|l|}{ Bus } & \multicolumn{3}{l|}{ Penumpang } \\
\cline { 2 - 7 } & Datang & Berangkat & Jumlah & Datang & Berangkat & Jumlah \\
\hline Februari & 5618 & 6870 & 12488 & 50459 & 77246 & 127705 \\
\hline Maret & 5518 & 6415 & 11933 & 40435 & 72085 & 112520 \\
\hline April & 956 & 1794 & 2750 & 5001 & 15097 & 20098 \\
\hline Jumlah & 12092 & 15079 & 27171 & 95895 & 164428 & 260323 \\
\hline
\end{tabular}

Berdasarkan tabel diatas, menunjukkan bahwa di Terminal Terpadu Pulogebang

$\%$ Kedatangan Bus

$\equiv \sum$ (selisih datang Februari - berangkat April)x 100 Jumlah bus yang datang

$=5618-956 \times 100 \%$ 12092

$=38,56 \%$

$\%$ Penumpang berangkat

$\equiv \sum$ (selisih berangkat Februari - bulan April ) x 100 Jumlah peumpang yang berangkat

$=(77246-15097) \times 100 \%$ 164428

$=37,79 \%$

$\%$ Penumpang Datang

$=\sum($ selisih berangkat Februari - bulan April $) \times 100$ Jumlah bus yang berangkat Persentase

= berangkat Februari x 100

Jumlah penumpang yang datang

$=(50459-5001) \times 100 \%$ 95895

$=47,40 \%$

Dari hasil perhitungan, diketahui jumlah penurunan volume bus yang berangkat melalui Terminal Terpadu Pulo Gebang sebesar 33,67\%. Sedangkan untuk penurunan volume bus yang datang sebesar 38,56\%. Agar terlihat jelas persentase volume bus yang datang dan 
berangkat dmelalui Terminal Terpadu Pulo

Gebang, maka disajikan grafik pada sebagai berikut..

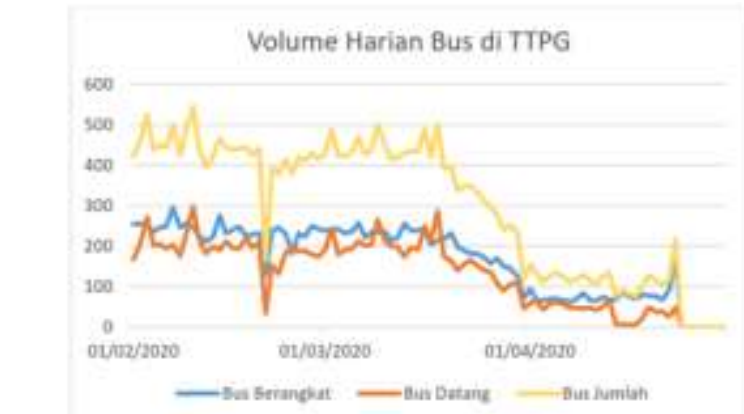

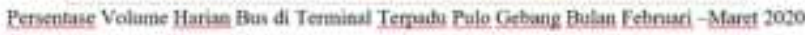
Sumber Tenminal Terpata Pole Getous

Dari hasil perhitungan, diketahui jumlah penurunan volume penumpang yang berangkat melalui Terminal Terpadu Pulo Gebang sebesar 37,79\%. Sedangkan untuk penurunan volume penumpang yang turun di Terminal Pulo Gebang sebesar 47,40\%.

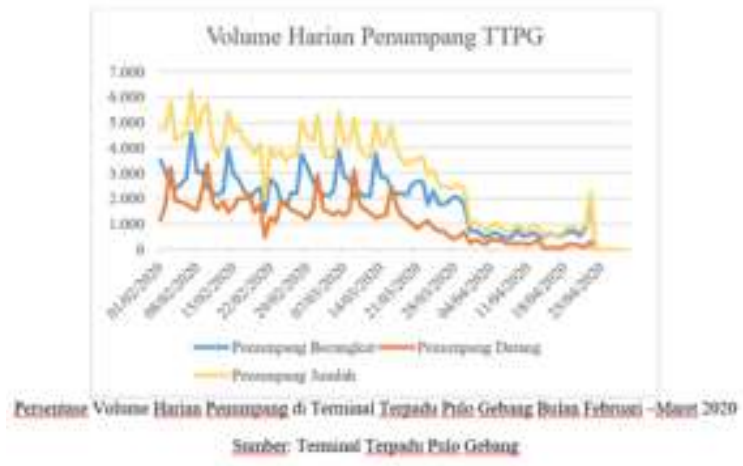

\section{Kesimpulan}

Berdasarkan hasil analisis dan observasi lapangan dengan menggunakan kuesioner yang dibagikan kepada 150 orang dapat disimpulkan sebagai berikut:

1. Dari hasil penyebaran kuesioner menyatakan bahwa perjalanan responden mengalami penurunan pada maksud perjalanan pekerjaan $28 \%$, pendidikan $34 \%$, sosial $23 \%$ dan rekreasi $36 \%$. Sedangkan untuk perjalanan dengan maksud pusat perbelanjaan tidak terpengaruh dengan adanya pandem Covid-19

2. Jumlah pergerakan responden setelah terjadinya pandemi Covid 19 sampai dengan PSBB berkurang sebesar $38 \%$. Menunjukan bahwa banyak yang telah melakukan work from home (WFH), belajar dan beribadah di rumah.

3. Masih ditemukan responden yang melakukan perjalanan ke luar Jabodetabek meskipun telah berkurang $21 \%$ dimasa pandemi. Karena melakukan perjalanan ke luar daerah Jabodetabek bisa jadi merupakan salah satu penyebab meningkatnya virus di daerah lain.

4. Dengan masuknya Pandemi Covid19 ke Indonesia khususnya di wilayah Jabodetabek banyak yang memilih beralih dari transportasi umum ke transportasi pribadi sebanyak $25 \%$. Kenaikan tertinggi terdapat pada moda sepeda motor dan mobil sebesar $10 \%$, peningkatan juga terjadi pada sepeda sebesar 5\%. Sedangkan 
penurunan terbanyak terjadi pada moda transjakarta sebesar $14 \%$.

\section{E. Daftar Pustaka}

Unit Pengelola Terminal Terpadu Pulo Gebang. 2019. Laporan Kinerja Tahun 2020 Rutin. Jakarta: Dinas Perhubungan.

Unit Pengelola Terminal Terpadu Pulo Gebang. 2019. Data Boarding Pass bulan Desember 2019 - Maret 2020.. Jakarta: Dinas Perhubungan.

Fakultas Teknik. 2014. Buku Panduan Penyusunan Tugas Akhir. Jakarta: Fakultas Teknik, Universitas Negeri Jakarta.

Badan Pusat Statistik. 2019. Statistik Komuter Jabodetabek. Jakarta: Badan Pusat Statistik

Andriansyah. 2015. Manajemen Transportasi Dalam kajian Teori, Jakarta: Fakultas Ilmu Sosial Dan Politik, Universitas Prof. Dr. Moestopo Beragama.

Maimunah S. 2010. Karakteristik Pergerakan Kendaraan Bermotor Di DKI Jakarta, Jakarta: Badan Litbang Perhubungan.

Sylvia Yazid dan Lie, Liliana Dea Jovita. 2020. Dampak Pandemi Terhadap Mobilitas Manusia di Asia Tenggara. Bandung: Universitas Katolik Parahyangan.
Presiden Republik Indonesia Menteri. 2020. Peraturan Pemerintah Nomor 21 Tahun 2020 Tentang Pelaksanaan Pembatasan Sosial Berskala Besar Dalam Rangka Percepatan Penanganan Corona Virus Disease 2019 (Covid-19). Jakarta: Pemerintah Republik Indonesia.

Gubernur DKI Jakarta 2020. Peraturan Gubernur Nomor 33 Tahun 2020 Tentang Pelaksanaan Pembatasan Sosial Berskala Besar Dalam Rangka Percepatan Penanganan Corona Virus Disease 2019 (Covid-19). Jakarta: Pemerintah Provinsi DKI Jakarta 